\title{
EFFECTS OF ACTIVE LEARNING METHODOLOGIES ON THE STUDENTS' EMOTIONS, SELF-EFFICACY BELIEFS AND LEARNING OUTCOMES IN A SCIENCE DISTANCE LEARNING COURSE
}

\author{
Jin Su Jeong ${ }^{1}$ (D) , David González-Gómez ${ }^{2}$ (D), Florentina Cañada-Cañada ${ }^{2}$ (iD), \\ Alejandrina Gallego-Picó ${ }^{3}$ (D) Juan Carlos Bravo ${ }^{3}$ iD \\ ${ }^{1}$ Universidad Politécnica de Madrid (Spain) \\ ${ }^{2}$ Universidad de Extremadura (Spain) \\ ${ }^{3}$ Universidad Nacional de Educación a Distancia (Spain) \\ jinsu.jeong@upm.es,dggome:@unex.es,flori@unex.es,agallego@ccia.uned.es,juancarlos.bravo@ciemat.es
}

Received September 2018

Accepted November 2018

\section{Abstract}

Distance education programs in higher education are gaining popularity mostly due to the flexibility of the formative programs to fit all the requirements that brick-and-mortar educational institutions are not able to provide to students. However, quite often these distance programs report feelings of isolation, lack of self-direction and management, and eventual decrease in motivation levels. Thus, the main aim of this research is to assess the effect of following an active learning methodology on the students' emotions, self-efficacy beliefs and learning outcomes in the context of a distance learning program in an Atmospheric Pollution course. According to the results, the use of these methodologies not only had a significant promotion in the positive emotions and self-efficacy beliefs, but also better learning outcomes were achieved by the students following this methodology. The results obtained in this research demonstrate that following an appropriate learning methodology in a distance program could contribute to reduce the main handicaps of these programs.

Keywords - Active learning, Distance learning, Emotions, Self-efficacy, Science education.

\section{To cite this article:}

Jeong, J.S., González-Gómez, D., Cañada-Cañada, F., Gallego-Picó, A., \& Bravo, J.C. (2019). Effects of active learning methodologies on the students' emotions, self-efficacy beliefs and learning outcomes in a science distance learning course. Journal of Technology and Science Education, 9(2), 217-227. https://doi.org/10.3926/jotse.530

\section{Introduction}

Distance learning has become a mainstream in higher education. According to Kentnor's study (2015) from 2007 to 2012, the number of students enrolled in any distance program in the United States increased $18.8 \%$ as average, and since then this figure maintains a growing rate of nearly $5 \%$. The same tendency is observed in Spain, where the number of students enrolled in National Distance Education University (Universidad Nacional de Educación a Distancia - UNED) has increased in around 33\% from 
2001 up until now. Currently, the number of students enrolled in 2017 was 207,000 which makes UNED the biggest university in terms of enrolled students in the whole country (UNED, 2018). Ludwing-Hardman and Dunlap (2003) suggested that this significant growth is due to the fact that distance learning programs satisfy many of the obstructions that conventional campus-located educational programs have, such as the need to attend classes that normally means a geographical relocation, conflicts between work and course schedules and family commitment conflicts. Although the great accessibility of Internet and the technological revolution have definitely contributed to the noticeable expansion of the distance and online programs in higher education (Kurzman, 2013), the main pitfalls of distance programs must be found in the effects of the fact that students and teachers are not in the same physical place, causing a growth of an "isolation feeling, lack of self-direction and management, and a decrease in motivation levels" (Ludwing-Hardman \& Dunlap, 2003: page 1) because of the lack of interaction (Ludwing-Hardman \& Dunlap, 2003; Ali \& Smith, 2015). The effects of this isolation not only influenced the students' academic achievements, but also the promotion of negative attitudes and dissatisfaction with the learning experience causing even course withdrawal (Thompson, 1990; Ali \& Smith, 2015).

Learning strategies play an important role in the acquisition of knowledge (Weinstein, Acee \& Jung, 2011), in addition they are often related with self-regulation learning, motivation and emotion (Abar \& Loken, 2010). Extensive evidence suggests that non-traditional instructions are able to promote academic achievement and positive student attitudes and some studies indicate the effectiveness of active learning as it was reviewed by Prince (2004) to carry out authentic tasks such as scientific inquiry and other critical thinking activities to promote self-regulated learning particularly in a science course. The skills implicated in these activities require the cognitive, motivational, metacognitive processes of planning, reflecting, evaluating, and revising strategies based on outcomes (Sinatra \& Taasoobshirazi, 2011). Active learning is defined as any instructional method that engages the students in the learning process. That requires the students to do meaningful learning activities and think about what they are involved more cognitive processing and meaning building (Prince, 2004). When the students engaged in active and authentic tasks, they were more likely to plan and evaluate their learning. A review of effective instructional approaches for promoting self-regulation in students has found that these activities improve their success in solving problems and engaging in inquiry and critical thinking (Sinatra \& Taasoobshirazi, 2011). On the other hand, active learning strategies supplement the lack of practical skills acquired by the students in distance education, which have important implications for labor market transition. These activities are able to bring the students closer to the professional world, which demands the acquisition of cognitive and metacognitive skills (Bahri \& Corebima, 2015). Active methods make up resources that allow learning through practice. Thus, the students have to adapt their conceptual knowledge to the given task and then reflect on what the experience means, and the practice is an essential part of the learning experience and the elaboration of strategies require active cognitive processing on the part of the learner (Weinstein et al., 2011). In this kind of instruction, the design of learning activities takes a significant value (see Figure 1). In a recent study, several factors that have an influence on the design of learning activities have been described and assessed (Flores \& Gómez, 2017).

The influence of the affective dimension in the students' learning process is already discussed in many studies (Abrahams, 2009; Bellocchi, Ritchie, Tobin, Sandhu \& Sandhu, 2013; Dávila-Acedo, Borrachero, Cañada-Cañada, Martinez \& Sánchez, 2015; Dos Santos \& Mortimer, 2003; Ritchie, Tobin, Hudson, Roth \& Mergard, 2011; Schutz \& Zembylas, 2011; Zembylas, 2007), concluding that the emotions play an important role in the whole teaching-learning process, especially in scientific disciplines (Pintrich, Marx \& Boyle, 1993; Mellado, Borrachero, Brígido, Melo, Dávila, Cañada et al., 2014). The teaching strategy followed in a course might consider the students' emotions that are involved in the learning process, and the course must be designed to foster positive emotional states in order to help the students to learn (Vázquez \& Manassero, 2007; Aydogan, Bozkurt \& Coskun, 2015). On the other hand, different studies suggest that students' negative emotions are normally associated with dissatisfaction of the learning experience, especially in science courses (Brígido, Bermejo, Conde \& Mellado, 2010; Solbes, 2011; Brígido, Borrachero, Bermejo \& Mellado, 2013). Thus, in order to foster positive emotions in the students, and 
therefore causing a positive impact in the learning process, the course should be designed considering teaching strategies and instruction methodologies that contribute to control and regulate the students' affective dimensions evolved in the learning-teaching process and foster students' favorable attitude (Brígido et al., 2010). Bandura (1997) defined the self-efficacy as a subjective judgement of one's level of competence in executing certain behaviors or achieving certain outcomes in the future, that refers to the confidence a person has to think that they can do what they have to do. From an educational point of view, self-efficacy is related with the students' motivation, performance and ability to develop their academic and professional interests and goals (Valentine, Dubois \& Cooper, 2004; Brown, Tramayne, Hoxha, Telander, Fan \& Lent, 2008).

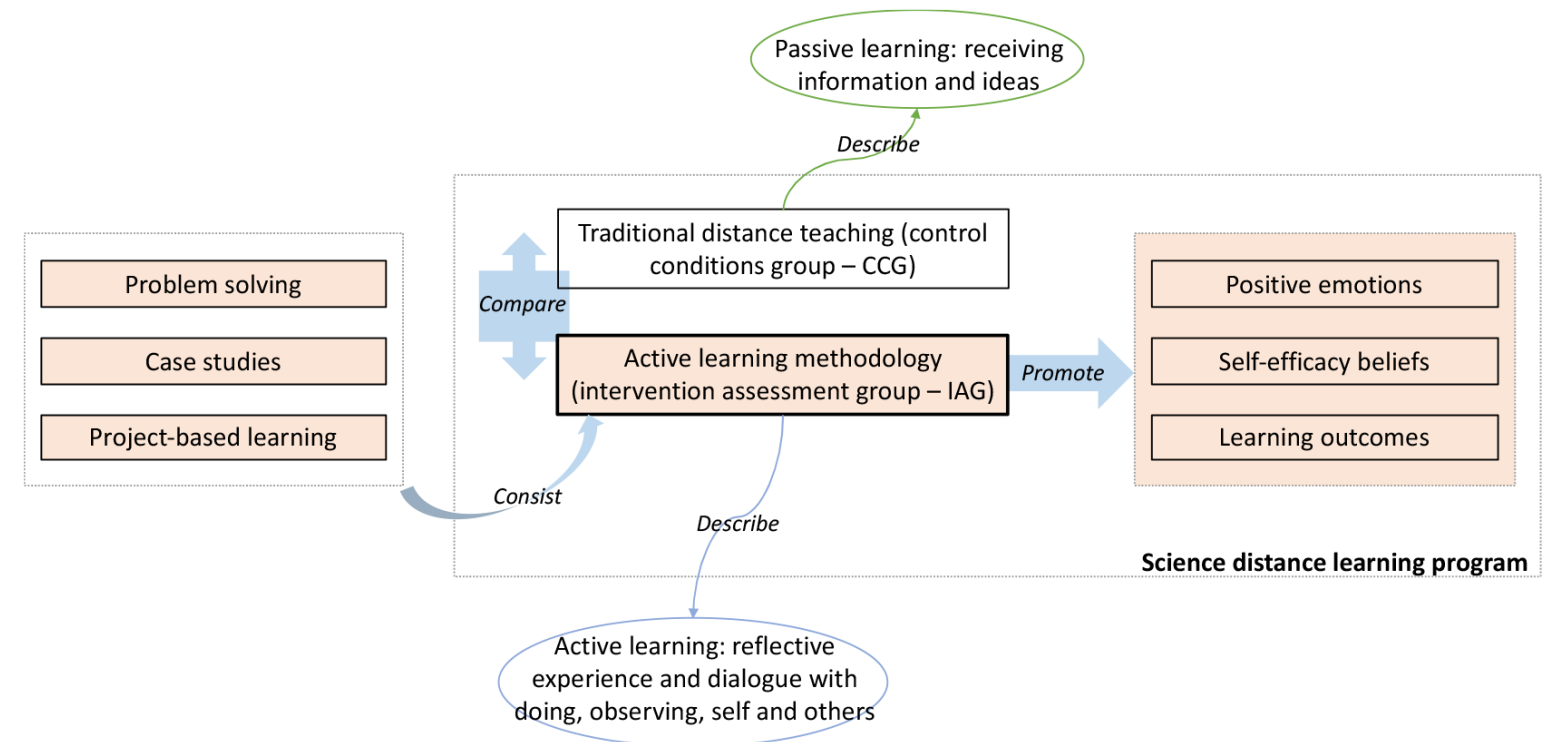

Figure 1. Process framework deployment of the study proposed, active learning activities' methodology

\section{Methodology}

The aim of this research is to assess how the emotions, self-efficacy and learning outcomes are affected by following active teaching methodologies in a distance course. To achieve this goal, a comparative study was carried out between a control group, in which a traditional distance methodology was used, and an intervention assessment group, in which an active learning methodology was applied, as it is explained in below.

\subsection{Sample}

The research was conducted with 231 students enrolled in the "Atmospheric Pollution course", a course of the Environmental Science undergraduate program of the UNED during the second semester of 2016/17 course year. The students participating in this research were randomly arranged into two groups. In the first group, a traditional distance teaching (control conditions group - CCG: $n=119$ ) was followed, and in the second group an active learning methodology applied to a distance program (intervention assessment group - IAG: $\mathrm{n}=112$ ) was followed. No constraints were imposed, and the students freely choose whether they wanted to participate in the research. The demographic description of the sample is summarized in Table 1.

\begin{tabular}{|c|c|c|c|c|c|c|c|c|c|c|c|}
\hline \multirow[b]{2}{*}{ Group } & \multirow[b]{2}{*}{$\begin{array}{c}\text { Sample } \\
\text { Size }\end{array}$} & \multicolumn{2}{|c|}{ Gender $(\%)$} & \multicolumn{4}{|c|}{ Age (\%) } & \multicolumn{2}{|c|}{ Enrollment (\%) } & \multicolumn{2}{|c|}{ Full time Student (\%) } \\
\hline & & Men & Women & $<25$ & $25-30$ & $30-40$ & $>40$ & $\begin{array}{l}\text { First } \\
\text { time }\end{array}$ & $\begin{array}{c}\text { More } \\
\text { than once }\end{array}$ & Yes & No \\
\hline CCG & 119 & 69.2 & 30.8 & 3.8 & 26.9 & 46.2 & 23.1 & 80.8 & 10.2 & 11.5 & 88.5 \\
\hline IAG & 112 & 41.7 & 58.3 & 10.7 & 23.8 & 34.5 & 31.0 & 90.5 & 9.5 & 25.0 & 75.0 \\
\hline
\end{tabular}

Table 1. Demographic description of the studied sample 


\subsection{Procedure}

The course is structured in 10 units dealing with different aspects of the atmosphere, its pollution, pollutants distribution and analysis, and the local, regional and global environmental consequences. It also includes the aspects of engineering control of air pollution and environmental laws and regulations. The course is taught over a distance program, and according with the course syllabus, the students need 125 hours to complete all the contents and assessments exercises. The students are given all the course materials, consisting of a text book edited specifically for this course together with a student's guide that includes supplementary references and some practical information about the course with the aim of providing the students with a global overview of the subject contents, the learning outcomes and the competencies that the students will develop during the course. A virtual classroom is also available to promote the communication between students and instructors. Thus, the virtual classroom constitutes the main interaction scenario between students and instructors and the collaborative work between students. On the other hand, asynchronous interaction allowed students to rethink and assess their own understanding of content before they posted their responses that facilitated reflective and self-assessment processes.

In the control group (CCG), a summative assessment was applied. In this group, the students must autonomously work the contents according the text book and the students' guide. They are also encouraged to participate in all the course activities, such as on-line discussions or by completing the activities suggested in the text book, although their grade will be only based on the final exam that they have to take at end of the course. Students belonging to the CCG could get personalized assistance and feedback from the teachers as they needed.

On the other hand, in intervention conditions (IAG), an active learning methodology adapted to distance learning environment was followed. This methodology consisted in providing students different case studies for each subject section. With the case study students were asked to explore how what they have learnt applies to real world situations. Each case study included a problem description, recommended literature, and a set of open-ended questions to be solved during the case solving. In most cases, the problem stated in the case study allows multiple potential solutions, and the answer can range from a one-paragraph to a fully developed group action plan, proposal or decision. Due to the intrinsic limitations of the distance setting, the students are provided with interactive educational materials through the virtual campus, such as podcast, hot potatoes exercises, lecture presentations, conceptual maps, and summaries of theoretical contents. Some of these activities are applied as a source of on-going feedback with the aim to improve teaching and learning and consequently as a tool of formative assessment (Gikandi, Morrow \& Davis, 2011). In addition, the instructor fostered the students' interaction and implication in the case study through different communication channels that are implemented in the distance course (asynchronous discussion forums). In order to motive and engage students to actively participate in these activities, the participation is graded during the discussion of the case. For each case study, the students need to submit a report addressing all the questions and solving the situations states in the case studies. The submission of all proposed activities is mandatory. The course final grade consists of the grades obtained in the different activities arranged during the course together with a final exam. Portfolio was other assessment tools employed to analyze the students' evolution in terms of learning contents and competences. Each student's portfolio includes self-assessment results, on-line and in-person test evaluations and the students' opinion surveys. Portfolio was a multimodal tool in the learning processes (Dysthe, Engelsen \& Lima, 2007).

\subsection{Instrument}

The instrument used in this research was an ad-hoc questionnaire designed based on previously published and validated works. Questionnaires were provided in the virtual campus during last week of the semester when the course was about to finish. It was anonymously and voluntarily completed. 
The questionnaire had three sections, as follows:

a) The first section was intended to collect students' descriptive information such as gender, age, educational background, course enrolment (first time or second/third time), and whether they were full time (or not) student.

b) The second section of the questionnaire was planned to assess students' emotions grown in the learning process in distance education setting, when a traditional (CCG) or active learning (IAG) methodology was followed. In this section, the students were questioned to score from 0 to 10 how often they felt the assessed emotions while taking the course, where 0 meant the lowest frequency and 10 the highest frequency of occurrence (Borrachero, Brígido, Mellado, Costillo \& Mellado, 2014; Dávila-Acedo et al., 2015; Jeong, González-Gómez \& Cañada-Cañada, 2016). The emotions taken into consideration in this study were sorted in two groups, specifically positive and negative emotions (Bisquerra, 2005; Damasio, 2005). Positive emotions included fun, confidence, enthusiasm, and tranquility, while the negative ones were nervousness, concern, boredom, and fear (Dávila-Acedo et al., 2015). Besides of the numerical scores, the students were also asked to justify the score given for each emotion.

c) The third section of the questionnaire consisted of 7 closed-ended questions aimed to gauge the development of students' self-efficacy in a distance learning program context. The students were asked to score each question using a 0 to 10 scale, where 0 meant strongly disagreed and 10 strongly agreed.

The questionnaire was also validated by a panel of researchers and professors, both for distance and non-distance education systems. Before sending it to whole sample, it was piloted in order to determine that it was properly designed.

\subsection{Data Analysis}

A descriptive analysis was firstly performed for being described as the most appropriate way to characterize, describe, and draw conclusions from the sample data (Etxeberria \& Tejedor, 2005; Borrachero et al., 2014; Jeong et al., 2016). In order to reach plausible conclusions about the effects of the assessed learning methodology, sample homogeneity was tested. The Shapiro-Wilk normality test was conducted in order to establish whether data was normally distributed or not. As the results, data were not normally distributed and therefore non-parametric statistical tests were conducted. Second, in order to establish the differences between the control and intervention assessment group, the Mann-Whitney test was applied. In all cases, the SPSS statistical (SPSS statistics 22.0) software was used. Additionally, comments provided by the participants to justify the scores provided for each emotion were transcribed, coded, and analyzed. The results were used to get a more specific idea of the cause of the score given to each emotion. Finally, the students' grades were compared by means of the Mann-Whitney test.

\section{Results}

In order to assess the effects of the learning methodology on the emotions felt by the students, they were asked to score the emotions felt during the course by means of the questionnaire described before. The scores provided by both groups were statistically compared using non-parametric tools (Mann-Whitney test). The results were summarized in Table 2.

In order to get a better understanding of the emotions felt by the students, the comments provided to justify their emotion scores were analyzed. Thus, the comments were transcribed, coded, and grouped in different categories. The selected categories were based on the results of the research carried out by Dávila-Acedo, Borrachero, Brígido and Costillo. (2014). According to this study, the causes that promote positive or negative emotions in science students can be grouped in three categories: the first category is related with the student by itself (learning capacity, learning motivation, and previous experiences); the second category is related with the subject (contents, tasks, and activities); and the third category is related 
with the course methodology (teaching methodology, assessment system, and professor's attitude). Results were summarized in Figure 2.

\begin{tabular}{|c|c|c|c|c|c|c|c|c|}
\hline \multirow[b]{2}{*}{ Group } & \multicolumn{8}{|c|}{ Emotion } \\
\hline & Fun & Confidence & Passion & Tranquility & Nervousness & Concern & Boredom & Fear \\
\hline CCG & $\begin{array}{r}5.23 \\
(2.67)\end{array}$ & $\begin{array}{c}6.00 \\
(2.10)\end{array}$ & $\begin{array}{r}5.46 \\
(2.82)\end{array}$ & $\begin{array}{r}5.35 \\
(2.31)\end{array}$ & $\begin{array}{c}6.23 \\
(2.08)\end{array}$ & $\begin{array}{r}6.73 \\
(1.90)\end{array}$ & $3.57(2.35)$ & $\begin{array}{r}5.00 \\
(2.65)\end{array}$ \\
\hline IAG & $\begin{array}{r}6.12 \\
(2.47)\end{array}$ & $\begin{array}{c}6.99 \\
(1.92)\end{array}$ & $\begin{array}{r}6.61 \\
(2.43)\end{array}$ & $\begin{array}{c}6.75 \\
(2.38)\end{array}$ & $\begin{array}{c}4.47 \\
(3.06)\end{array}$ & $\begin{array}{r}4.76 \\
(2.92)\end{array}$ & $1.90(2.01)$ & $\begin{array}{r}1.69 \\
(2.55)\end{array}$ \\
\hline Sig* & .118 & .026 & .055 & .006 & .002 & .000 & .001 & .000 \\
\hline
\end{tabular}

*Significance level was .05. Standard deviation is shown inside of brackets.

Table 2. Comparison of the mean scores (ranged from 0 to 10) given for each emotion by the participants of control and intervention assessment groups
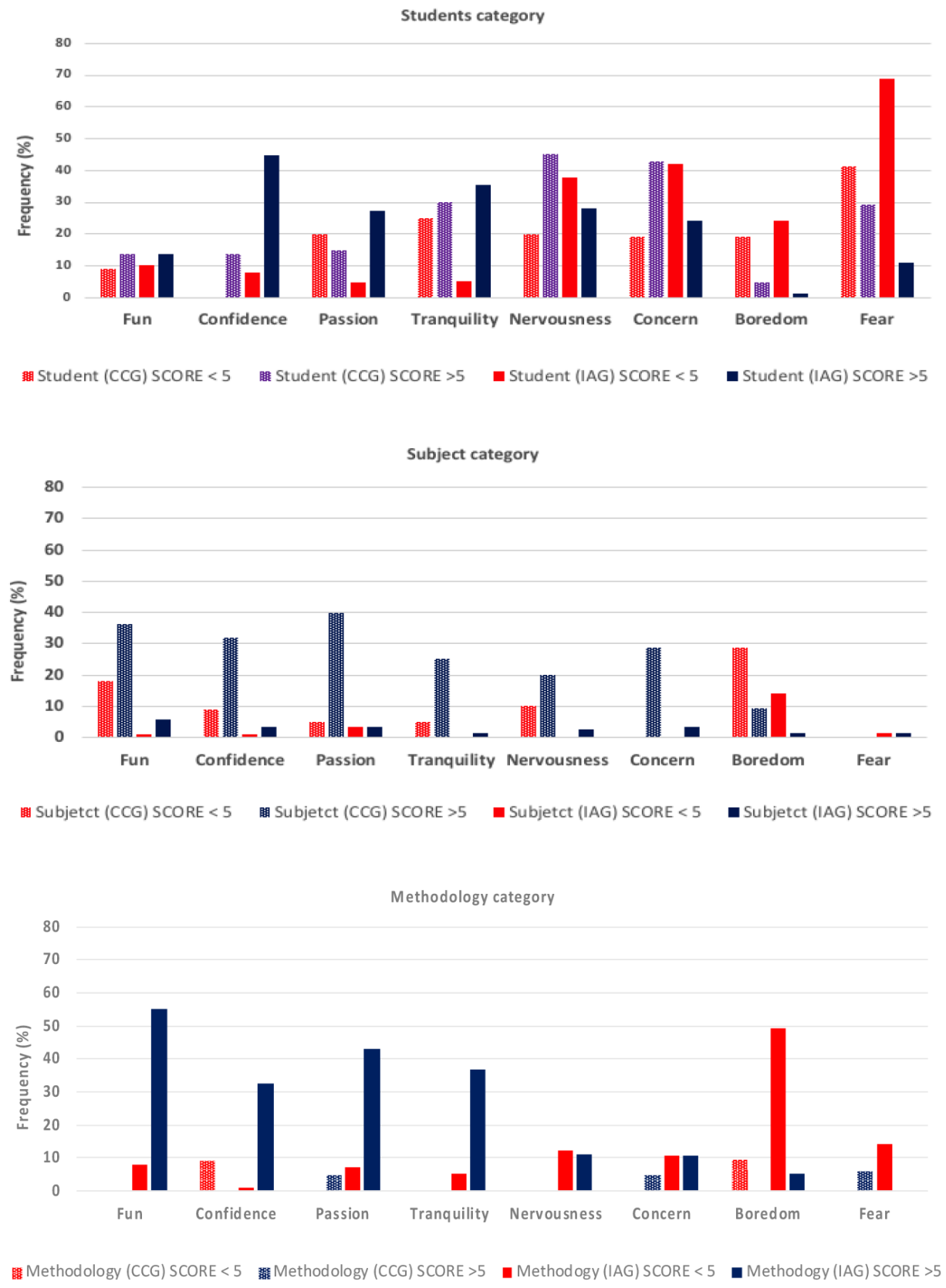

Figure 2. Frequency graph of the causes provided by the students to explain the scores given for each emotion.

Each graph summarized the category related with the student, subject and learning methodology 
With regard of the CCG group, score values over 5 points in the positive emotions were mainly due to the students' category (learning capacity, learning motivation, and previous experiences) as it is shown in Figure 2. This group of students did not consider the class methodology as a significant variable in fostering the positive emotions. On the other hand, regarding the ICG group, score values over 5 points in the positive emotions were more frequently due to the methodology category (teaching methodology, assessment system, and professor's attitude). From this figure, it is noticeable that learning methodology was the main reason to feel the emotion "fun" for more than $50 \%$ of the participants of the intervention assessment group. On the other hand, the causes included in the students' category (learning capacity, learning motivation, and previous experiences) were reported by both groups to be the main reason to feel or not negative emotions. In the case of the CCG group, these participants also pointed out that categories group in the "subject category" were also among the reasons to feel negative emotions. Finally, the IAG group considered that the learning methodology contributed to decrease the feeling of "boredom".

Regarding the students' self-efficacy beliefs with regard the learning method, a closed-ended questionnaire as described in the methodology section was used. Table 3 shows the list of self-efficacy questions and summarizes the scale scores given for each item by the students enrolled in the control and intervention assessment group. The non-parametric Mann-Whitney test was used to foresee the significant differences of the teaching methodology.

Finally, in order to assess the influence of the learning methodology in the students' learning outcomes, the final grades were statically compared by means of the Mann-Whitney test. The average grades obtained by the students enrolled in the control group was $4.43 \pm 2.53$ while in the intervention assessment group was $6.52 \pm 2.20$, being these values statistically different. Considering only the grade of the final exam that was the same for both groups, the average grade for the intervention group was $5.93 \pm 2.28$, while in the control group was $4.43 \pm 2.53$.

In addition, the analysis of the grade's information (see Figure 3) showed that in the control group the vast majority of students had grades below than 7 and no one got grades higher than 9, while in the intervention assessment group the majority of students got grades higher than 7 and around $9 \%$ more than 9 . In all cases the grade scale was from 0 to 10.

\begin{tabular}{|l|r|r|r|}
\hline \multicolumn{1}{|c|}{ Item } & CCG & IAG & \multicolumn{1}{c|}{$\begin{array}{c}\text { Level of } \\
\text { significance }\end{array}$} \\
\hline $\begin{array}{l}\text { I can get good results without much } \\
\text { efforts }\end{array}$ & $4.92(1.92)$ & $6.40(2.68)$ & $<.05$ \\
\hline $\begin{array}{l}\text { I have been able to overcome the } \\
\text { problems arise during the course }\end{array}$ & $5.61(2.61)$ & $7.91(1.50)$ & $<.05$ \\
\hline $\begin{array}{l}\text { I have been able to understand the } \\
\text { concepts worked during the course }\end{array}$ & $7.39(1.86)$ & $7.93(1.49)$ & $<.05$ \\
\hline $\begin{array}{l}\text { I have been able to apply all } \\
\text { necessary resources to achieve the } \\
\text { course learning goals }\end{array}$ & $6.04(2.94)$ & $8.44(1.31)$ & $<.05$ \\
\hline $\begin{array}{l}\text { I have been able to apply the } \\
\text { dispersion models }\end{array}$ & $4.07(3.07)$ & $8.45(1.39)$ & $<.05$ \\
\hline $\begin{array}{l}\text { I have been able to calculate the } \\
\text { efficiency of the emissions control } \\
\text { devices }\end{array}$ & $4.73(3.11)$ & $8.57(1.25)$ & $<.05$ \\
\hline $\begin{array}{l}\text { I have been able to estimate the } \\
\text { emissions of a particular industrial } \\
\text { area }\end{array}$ & $5.23(3.28)$ & $8.39(1.57)$ & $<.05$ \\
\hline
\end{tabular}

Table 3. Self-efficacy score comparison of the participants of control and intervention assessment group 


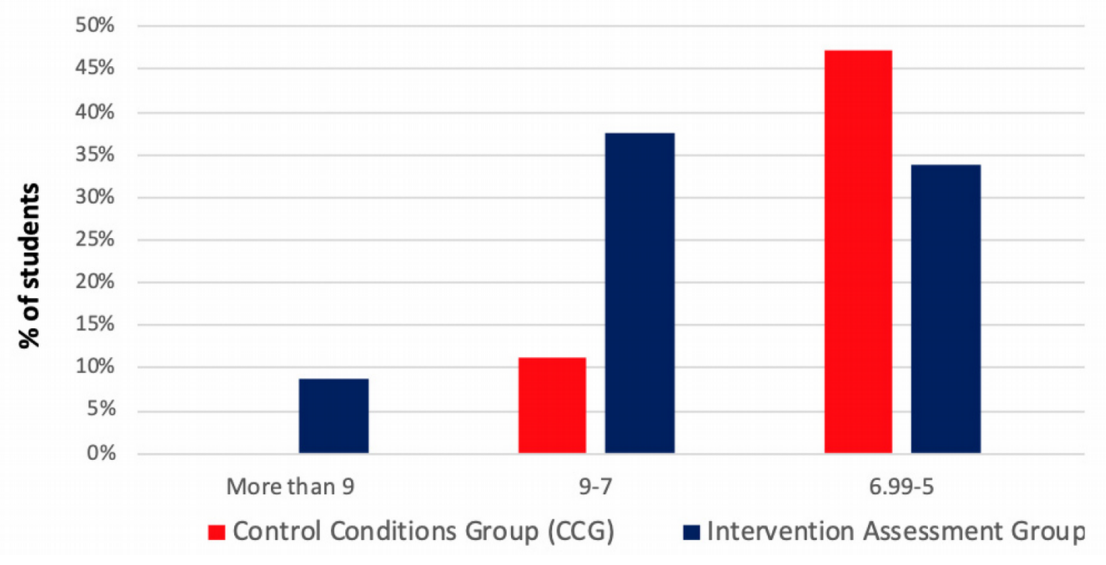

Figure 3. Distribution of the grades obtained by the students after completing the course

\section{Discussion}

According to the results obtained after comparing both learning methodologies in terms of students' emotions, no significant differences were shown between the scores given for both groups to the emotions "fun" and "passion". For the other assessed positive emotions ("confidence" and "tranquility"), the IAG group scored them with higher values, and these values were significantly higher than in the control group. Thus, following an active learning strategy, as the case study, in a distance learning program contributes to achieve a more effective learning, since it was reported that fostering positive emotional states in a course helps students to learn (Vázquez \& Manassero, 2007; Aydogan et al., 2015). Regardless of the negative emotions, in all cases the intervention assessment group gave significant lower scores than the control group. These differences were highly significant $(p<.00)$ for "concern" and "fear". Thus, an active learning methodology reduces the negative emotions in the students could contribute to increase the students' satisfaction with the learning experiences, as it was suggested in previous studies (Brígido et al., 2010, 2013; Solbes, 2011). Promoting positive emotions has a relevant importance in a distance learning program, where it was reported that negative attitudes and dissatisfaction with the learning experience were among the main pitfalls of the distance learning programs (Thompson, 1990; Ali \& Smith, 2015). With regard of the control group, score values over 5 points in the positive emotions were mainly due to the students' category (learning capacity, learning motivation, and previous experiences) and the course subject category (contents, task or activities) as it is shown in Figure 2. Similar results were described in Dávila-Acedo et al. (2014) report, where the main causes reported by the students when feeling positive emotions were mostly due to themselves.

With regard to effects of the learning methodology on the students' self-efficacy beliefs, and according to the results obtained in this research, the participants of the intervention group (IAG) showed higher self-efficacy beliefs than those from the control group (CCG). The differences between both groups were statistically significant for all items but one item (item 3) as shown in Table 3. The higher scores for self-efficacy beliefs were reported for those items directly related with the application of the course learnt skills (items 4 to 6). Higher scores of self-efficacy beliefs to achieve a particular task have been associated with a better performance and more enjoyment while achieving a task. On the other hand, lower scores in self-efficacy beliefs have been associated with a higher anxiety to fail (Perrenoud, 1996). Therefore, the following an active learning methodology in a distance learning context also contributes to reduce the anxiety to fail. In addition, Ludwing-Hardman and Dunlap (2003) and Ali and Smith (2015) indicated that the lack of interaction between teachers and students in distance learning programs were one of the causes to grow insolation feeling and lack of self-direction, management and a loss of motivation. Different authors (Valentine et al., 2004; Brown et al. 2008) indicated that promoting self-efficacy beliefs are related with the promotion of the students' motivation, performance and ability to develop their academic and professional interests and goals, and therefore this is another positive consequence of following this active methodology in a distance learning context. 
According to the results regarding the students' learning outcomes, it can be overserved that following an active learning methodology not only has a positive effect in the students' emotions and self-efficacy beliefs, but also in their learning outcomes in the context of a distance learning program.

\section{Conclusions}

This research aimed to assess the influence of following an active learning methodology in a distance learning program in terms of the promotion of positive emotions, self-efficacy and learning outcomes in a science course. According to the results, following an active learning methodology in the context of a distance learning science program had a positive impact in the promotion of positive emotions. Higher score values to the positive emotions and lower scores to the negative ones were given by the students enrolled under the intervention conditions (IAG). After analyzing the causes reported by the participants to justify their emotions, the positive emotions in the IAG were due to the learning methodology followed in the course. With regard the self-efficacy beliefs, the active learning methodology proved to be effective to promote them. As it was mentioned before, higher scores of self-efficacy beliefs to achieve a particular task had been associated with a better performance and more enjoyment while achieving a task. Finally, regarding the learning outcomes, higher grades were obtained by the IAG students, and the number of students getting more than 7 points, in a 0 to 10 scale, was also higher that in the CCG group.

\section{Declaration of Conflicting Interests}

The authors declared no potential conflicts of interest with respect to the research, authorship, and/or publication of this article.

\section{Funding}

This work was financed by Research Project EDU2016-77007-R (AEI/FEDER, UE) of the Ministry of Economy and Competitiveness of Spain.

\section{References}

Abar, B., \& Loken, E. (2010). Self-regulated learning and self-directed study in a pre-college sample. Learning and Individual Differences, 20, 25-29. https://doi.org/10.1016/j.lindif.2009.09.002

Abrahams, I. (2009). Does practical work really motivate? A study of the affective value of practical work in secondary school science. International Journal of Science Education, 31(17), 2335-2353. https://doi.org/10.1080/09500690802342836

Ali, A., \& Smith, D. (2015). Comparing social isolation effects on students' attrition in online versus face-to-face courses in computer literacy. Issues Inform Sci Inform Technol, 12, 11-20. https://doi.org/10.28945/2258

Aydogan, H., Bozkurt, F., \& Coskun, H. (2015). An assessment of brain electrical activities of students toward teacher's specific emotions. International Journal of Social, Behavioral, Educational, Economic, Business and Industrial Engineering, 9(6), 1977-2000.

Bandura, A. (1997). Self-efficacy: The exercise of control. Freeman, New York.

Bahri, A., \& Corebima, A.D. (2015). The contribution of learning motivation metacognitive skill on cognitive learning outcome of students within different learning strategies. Journal of Baltic Science Education, 14(4), 487-500.

Bellocchi, A., Ritchie, S.M., Tobin, K., Sandhu, M., \& Sandhu, S. (2013). Exploring emotional climate in preservice science teacher education. Cultural Studies of Science Education, 8(3), 529-552.

https://doi.org/10.1007/s11422-013-9526-3

Bisquerra, R. (2005) Emotional education and well-being. Praxis, Barcelona. 
Borrachero, A.B., Brígido, M., Mellado, L., Costillo, E., \& Mellado, V. (2014). Emotions in prospective secondary teachers when teaching science content, distinguishing by gender. Research in Science \& Technological Education, 32(2), 182-215. https://doi.org/10.1080/02635143.2014.909800

Brígido, M., Bermejo, M.L., Conde, M.C., \& Mellado, V. (2010). The emotions in teaching and learning Nature Sciences and Physics/Chemistry in pre-service primary teachers. US-China Educational Review, 7(12), 25-32.

Brígido, M., Borrachero, A.B., Bermejo, M.L., \& Mellado, V. (2013). Prospective primary teachers' self-efficacy and emotions in science teaching. European Journal of Psychology of Education, 36(2), 200-217.

Brown, S.D., Tramayne, S., Hoxha, D., Telander, K., Fan, X., \& Lent, R.W. (2008). Social cognitive predictors of college students' academic performance and persistence: a meta-analytic path analysis. Journal of Vocational Behavior, 72(3), 298- 308. https://doi.org/10.1016/j.jvb.2007.09.003

Damasio, A. (2005). Looking for Spinoza. Neurobiology emotion and feelings. Crtítica, Barcelona.

Dávila-Acedo, M.A., Borrachero, A.B., Brígido, M., \& Costillo, E. (2014). Emotions and its causes in the learning of physics and chemistry. International Journal of Educational Psychology, 1(4), 287-294.

Dávila-Acedo, M.A., Borrachero, A.B., Cañada-Cañada, F., Martinez, G., \& Sánchez, J. (2015). Evolution of the emotions experienced by prospective primary teachers, focused on didactics of matter and energy. Revista Eureka sobre Ense-anza y Divulgación de las Ciencias, 12(3), 550-564.

Dos Santos, F.M.T., \& Mortimer, E.F. (2003). How emotions shape the relationship between a chemistry teacher and her high school students. International Journal of Science Education, 25(9), 1095-1110. https://doi.org/10.1080/0950069032000052216

Dysthe, O., Engelsen, K.S., \& Lima, I. (2007). Variations in portfolio assessment in higher education: Discussion of quality issues based on a Norwegian survey across institutions and disciplines. Assessing Writing, 12, 129-148. https://doi.org/10.1016/j.asw.2007.10.002

Etxeberria, J., \& Tejedor, F.J. (2005). Descriptive data analysis in education. La Muralla, Madrid.

Flores, V.M., \& Gómez, J. (2017). Applying Active Methodologies for Teaching Software Engineering in Computer Engineering. IEEE Revista Iberoamericana de Tecnologias del Aprendizaje, 12(3), 147-155. https://doi.org/10.1109/RITA.2017.2738178

Gikandi, J.W., Morrow, D., \& Davis, N.E. (2011). Online formative assessment in higher education: A review of the literature. Computers \& Education, 57, 2333-2351. https://doi.org/10.1016/j.compedu.2011.06.004

Jeong, J.S., González-Gómez, D., \& Cañada-Cañada, F. (2016). Students' Perceptions and Emotions Toward Learning in a Flipped General Science Classroom. Journal of Science Education and Tecbnology, 25(5), 747-758. https://doi.org/10.1007/s10956-016-9630-8

Kentnor, H.E. (2015). Distance education and the evolution of online learning in the United States. Curriculum \& Teaching Dialogue, 17(1-2), 21-34

Kurzman, P.A. (2013). The evolution of distance learning and online education. Journal of Teaching in Social Work, 33(4-5), 331-338. https://doi.org/10.1080/08841233.2013.843346

Ludwing-Hardman, S., \& Dunlap, J.C. (2003). Learner support services for online students: scaffolding for success. International Review of Research in Open and Distance Learning, 4(1), 1-8.

Mellado, V., Borrachero, A.B., Brígido, M., Melo, L.V., Dávila, M.A., Cañada, F. et al. (2014). Las emociones en la ense-anza de las ciencias (Emotions in the teaching of science). Enseñanza Ciencias, 32(3), 11-36. 
Perrenoud, P. (1996). La construcción del éxito y del fracaso escolar. Morata, Madrid.

Pintrich, P.R., Marx, R.W., \& Boyle, R.A. (1993). Beyond cold conceptual change: The role of motivational beliefs and classroom contextual factors in the process of conceptual change. Review of Educational Research, 63(2), 167-199. https://doi.org/10.3102/00346543063002167

Prince, M. (2004). Does active learning work? A review of the research. Journal of Engineering Education, 93(3), 1-10. https://doi.org/10.1002/j.2168-9830.2004.tb00809.x

Ritchie, S.M., Tobin, K., Hudson, P., Roth, W.M., \& Mergard, V. (2011). Reproducing successful rituals in bad times: Exploring emotional interactions of a new science teacher. Science Education, 95(4), 745-765. https://doi.org/10.1002/sce.20440

Schutz, P.A., \& Zembylas, M. (2011). Advances in teacher emotion research. Springer, Dordrecht.

Sinatra, G.M., \& Taasoobshirazi, G. (2011). The Self-regulation of Science learning. In Schunk, D.H., \& Zimmerman, B. (Eds.), Handbook of Self-regulation of learning a performance. Taylor \& Francis.

Solbes, J. (2011). ¿Por qué disminuye el alumnado de ciencias? (Why decreases science students?). Alambique, 67, 53-61.

Thompson, G. (1990). How can correspondence-based distance education be improved? A survey of attitudes of students who are not well disposed toward correspondence study. International Journal of E-Learning \& Distance Education, 5(1), 53-65.

Valentine, J.C., DuBois, D.L., \& Cooper, H. (2004). The relation between self-beliefs and academic achievement: a meta-analytic review. Journal of Educational Psychology, 39(2), 111-33.

https://doi.org/10.1207/s15326985ep3902_3

Vázquez, A., \& Manassero, M.A. (2007). En defensa de las actitudes y emociones en la educación científica (I): Evidencias y argumentos generales (In defense of attitudes and emotions in science education (I): General arguments and evidence). Revista Eureka sobre Ense-anza y Divulgación de las Ciencias, 4(2), 247-271.

Weinstein, C.E., Acee, T.W., \& Jung, J. (2011). Self-regulation and learning strategies. New Directions for Teaching and Learning, 126, 45-53. https://doi.org/10.1002/tl.443

Zembylas, M. (2007). Emotional ecology: The intersection of emotional knowledge and pedagogical content knowledge in teaching. Teaching and Teacher Education, 23(4), 355-367.

https://doi.org/10.1016/j.tate.2006.12.002

UNED (2018). Available at: http://portal.uned.es/portal/page? pageid=93,25170900,93 59732186\& dad= portal\&_schema=PORTAL

Published by OmniaScience (www.omniascience.com)

Journal of Technology and Science Education, 2019 (www.jotse.org)

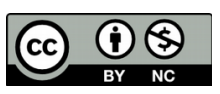

Article's contents are provided on an Attribution-Non Commercial 4.0 Creative commons International License. Readers are allowed to copy, distribute and communicate article's contents, provided the author's and JOTSE journal's names are included. It must not be used for commercial purposes. To see the complete licence contents, please visit https://creativecommons.org/licenses/by-nc/4.0/. 